\title{
The effect of flipped learning strategy on handball outcomes for Faculty of physical Education students, Mansoura University *Dr/ Tamer Mahmoud Elsaid Mohamed
} Abstract

The research aims to identify the effect of the flipped learning strategy on handball learning outcomes (skill, cognitive, affective) for students of the Faculty of Physical Education at Mansoura University. The researcher used the experimental curriculum, and the sample of the research was represented in the students of the second year in the Faculty of Physical Education University Mansoura in the second semester of the academic year 2018/2019 and numbered (94) students were randomly distributed to two groups, one experimental consisting of (47) students were taught with an flipped learning strategy, and the other control consisting of (47) students was taught in the traditional method, and to achieve aim of the study, the researcher designed the electronic course of handball through the website of the Electronic Learning Unit of Mansoura University, and applied the skill tests cognitive achievement test and the attitude scale towards the pre and post for the study groups, and took the duration of (12) weeks for application of the study. The researcher concluded that the use of the flipped learning strategy had a positive effect on improving learning outcomes in handball for students of the second year at the Faculty of Physical Education, Mansoura University.

Keywords: Flipped learning, Handball, learning outcomes, Physical Education

\section{Introduction:}

Technological developments in computer science, communication and internet technologies have contributed to doing a qualitative shift in the educational system and encouraging teachers to employ those techniques to serve the educational process and develop learning styles and its means to improve the quality of learning outcomes and to achieve the needs and interests of students and enhance their motivation,

* Assistant professor at Department of Curricula and teaching methods of physical Education, Faculty of physical Education, Mansoura University, Egypt.

Assiut Journal For Sport Science Arts 
which led to the emergence of teaching strategies coping with the continuous changes in modern education technology enabling the student to interact with the content at any time and from anywhere and communicate with the teacher and among them. E-learning, built-in learning, learning in cognitive journeys, and flipped learning.

Alsobaie (2018, 17-18) points out that flipped learning encourages teachers to introduce their curriculum in a flexible, adjustable and attractive manner that increases students' participation and interest, in a suitable educational environment for all using available technological media, where students are introduced to educational content at home by watching pre-recorded videos by the teacher and they attend the classroom to apply and discuss their questions with their teachers and peers.

Roehling (2018, 3-4) mentions that there are four pillars that support flipped learning they are:

- Providing a flexible learning environment that takes into considerations students' attitudes and abilities.
- The shift of learning culture to the transition from focusing on the teacher as being a source of knowledge to the student to become the axis of the educational process and to be an active participant in building knowledge and applying concepts.

- Teachers care about the accurate thinking in all the content parts which are introduced to the students outside the class, and the activities which attract student inside the class to achieve the aims of course.

- Providing professional teachers who set up and organize experience, activities and practice to make the flipped learning strategy successful.

Heredia (2015, 13) believes that flipped learning is a teaching model in which students watch lectures through online videos at home without any time restrictions, participate teaching based on computers outside the classroom, and use interactive group learning activities to apply concepts and practices inside the classroom, giving time for questions and group interaction inside the classroom the next school day. 
Rashid (2017, 156) mentions that flipped learning is one of the modern teaching strategies that takes into consideration the abilities, needs and inclinations of learners and helps them to learn quickly away from traditional methods, and relies on the use of education technology and the Internet in a way that allows the teacher to prepare the course through videos, audio files or other educational media for students to see at home before attending the lecture and devote lecture time to discussions and training.

Al-Kahaili (2015, 160) summarizes the stages of the performance of flipped learning in six stages they are:

- Identifying the subject or lesson to be inverted provided that it is valid.

- Analyzing the content into values, knowledge and skills.

- Designing an educational or interactive video that includes scientific material by sound and image in ten minutes.

- Directing learners to watch video online or on CDs at home at any time.

- Applying the learned activities in class time.

- Evaluating the educational and visual material in the classroom using the appropriate evaluation tools.
Flick (2019, 36-40) notes that the flipped learning strategy is a mixed learning model that increases cognitive achievement and improves learning outcomes for students and allows teachers to support their students individually for the difficult parts of the content, which is the current trend, in education that strengthens differentiated education and allows teachers to create their own learning style with unique learning for students, a repeatable and developed strategy that is easy for teachers and increases active participation and student collaboration, quick learning and time for activities and skills training, and students begin watching videos or read about a new concept online before coming to class.

\section{Research problem:}

Handball course is one of the practical courses that need to be taught using modern educational strategies to keep pace with the scientific, technical and technological revolution that the world is witnessing today, and one of the reasons that led the researcher to conduct this research is what he observed through his work in the faculty of physical education University Mansoura that some faculty members follow traditional teaching syles without paying attention to the participation of students in the 
educational process, which led to the abandon of students from attending lectures, and noticeable neglect in the performance of tasks, assignments and the low level of educational achievement. And negative trends towards the course, which prompted the researcher to think about a teaching strategy that may contribute to the solution of this problem and raise the level of educational and skillful achievement and gain students positive directions towards the course and make them the center of the educational process.

In light of the recommendations of some previous studies of the effectiveness of the strategy of flipped learning, especially in the stage of university education such as Prepose (2015), Abdul Latif (2016), Study Abdul Zahir (2016), ElShamy Study (2017) and Zaghloul Study (2017), Mahmoud Study (2018), Amin And Balbas Study (2018), Callahan (2018), Albishi (2018), which reached the effectiveness of the flipped learning strategy in developing the level of cognitive achievement, practical skills and attitudes of students towards using this strategy in education and learning.
Since most students spend most of their time on the world wide web of information using modern technologies such as smartphones, laptops, iPads, tablets and others, the researcher realized to use the flipped learning strategy as a modern necessity to adapt modern technologies and integrate them into the educational process to add excitement, pleasure and suspense and increase the motivation of students towards learning and improve the level of cognitive achievement and skills they have in handball, which prompted the researcher to conduct this study to learn about the impact of the flipped learning strategy on the learning outcomes of the learning in the university school of education college. Mansoura.

\section{Research aims:}

The research aims to identify the effect of the flipped learning strategy on handball learning outcomes (skill, cognitive, affective) for students of the Faculty of Physical Education at Mansoura University.

The importance of research: 
The importance of research stems from the follows:

- The extent of its contribution to achieving learning outcomes in handball for students of the Faculty of Physical Education University of Mansoura.

- To keep up with contemporary educational trends, which call for the employment of technological innovations in education.

- Focusing on the participation of the learner and his activity in the learning process and considering him as the focus of the educational process.

- Highlighting the importance of flipped learning strategy as one of the modern teaching strategies that achieves the uniqueness and independence of education.

\section{Research hypotheses:}

1- There are statistically significant differences between the means of pre-test and posttest measurements of the control group in handball learning outcomes for students of the Faculty of Physical Education University of Mansoura in favor of post-test measurement.

2- There are statistically significant differences between the means of pre-test and posttest measurements of the experimental group in handball learning outcomes for students of the Faculty of Physical Education University of Mansoura in favor of post-test measurement.

3-There are statistically significant differences between the means of the two post-test measurements of the control and experimental groups in handball learning outcomes for students of the Faculty of Physical Education university of Mansoura in favor of the post-test measurement of the experimental group.

\section{Research concept:}

\section{* Flipped Learning:}

A form of integrated learning in which traditional learning is integrated with e-learning, where students watch lectures on the learning management system through the university's website in their homes or anywhere using computers or mobile phones before the time of the lecture, and devotes lecture time to application and training and discuss the content, activities and assignments of the course.

\section{Research procedures:}

* Procedural definition 
Research methodology:

The researcher used the experimental approach due to its suitability for the nature of this research using one of the experimental designs which is the experimental design of two groups, one experimental and the other control using pre and post-test measurement of both groups.

\section{Research community:}

The students of the second year of the Faculty of Physical Education University Mansoura in the second semester of the university year 2018/2019 and the number of them (605) student represented the research community. The researcher believes the exclusion (174) students: (68) failed students, (23) external students, (6) students of handball players, (11) students with injuries, (66) students who are not regular in attendance, to become the research community after excluding these students (431) student.

\section{Sample search:}

The sample was selected in a random intended method from the research community and the sample size is (114) students $(26.45 \%)$ of the research community was divided into a basic sample of (94) students, a pilot sample of (20) students and a table (1) showing the description of the research community and sample.

Table (1)

Description of the research community and sample

\begin{tabular}{|c|c|c|c|c|}
\hline \multicolumn{2}{|c|}{ Total research community } & \multicolumn{3}{|c|}{ Research sample } \\
\hline Excluded & $\begin{array}{l}\text { Post-exclusion } \\
\text { research } \\
\text { community }\end{array}$ & \multicolumn{2}{|c|}{ Basic sample } & $\begin{array}{c}\text { Pilot } \\
\text { sample }\end{array}$ \\
\hline 174 & 431 & $\begin{array}{l}\text { Experimental } \\
\text { Group }\end{array}$ & $\begin{array}{l}\text { Control } \\
\text { Group }\end{array}$ & \multirow[t]{2}{*}{20} \\
\hline \multirow{2}{*}{\multicolumn{2}{|c|}{605}} & 47 & 47 & \\
\hline & & \multicolumn{3}{|c|}{114} \\
\hline \multicolumn{2}{|c|}{\begin{tabular}{l}
\multicolumn{2}{l}{ Experimental } \\
treatment materials: \\
It included: \\
First: means of collectin \\
data.
\end{tabular}} & \multicolumn{3}{|c|}{$\begin{array}{l}\text { Second: flipped learning } \\
\text { strategy. } \\
\text { First: Means of data } \\
\text { collection: } \\
1 \text {-Growth rates (age- height - } \\
\text { weight). }\end{array}$} \\
\hline \multicolumn{3}{|c|}{ Assiut Journal For Sport Science Arts } & & \\
\hline
\end{tabular}


2 -Physical abilities tests for handball skills under research. 3 -Skilled tests of handball skills under research.

4 -The cognitive test to measure the level of cognitive achievement in handball.

5- The attitude scale towards the handball course.

\section{1- Growth rates:}

-Age: (Age is calculated time for the nearest year).

-Height: The height was measured using the restameter (centimeter).

- Weight: Weight measured using a medical scale $(\mathrm{kg})$.

2- Physical abilities tests for handball skills under research: attachment (1)

The researcher identified the physical abilities tests for handball skills under research through scientific references such as Ismaeel and Hassanein (2001, 98-107), Darwish, Marsa, Abu Zeid (2002, 172197) and previous studies such as El-Shamy study (2015), and Abdul Razaq study (2016) and the tests were as follows:

- Running (30) meters from the high start to measure the speed of transition (second).

- $\quad$ Zigzag running by Barro to measure agility (second).
- Bend the trunk in front of the bottom of the stand to measure flexibility $(\mathrm{cm})$.

- Throw a handball to the furthest distance to measure the muscle strength of the pointed $\operatorname{arm}(\mathrm{M})$.

- Vertical jump of stability to measure the muscular strength of the two men $(\mathrm{cm})$.

- Shooting at overlapping rectangles to measure accuracy (degree).

\section{3- Skill tests of handball skills under research:} attachment (2)

The researcher identified the skill tests of handball skills under research through scientific references such as Ismaeel and Hassanein (2002, 68-179), Darwish, Marsa, Abu Zeid (2002, 140-149) and previous studies such as the study of Kurdi (2014), and the study of Abdul Razaq (2016) and the tests were as follows:

* Passing and receiving on the wall (30) second (number).

* Continuous dribbling for (30) Meter in a zigzag direction (second).

* The support step overhand shot (degree).

* The accuracy of the shot by jumping high (degree).

* Various defensive moves (number). 
* One-way defense blocking (number).

4- The cognitive test to measure the level of cognitive achievement in handball: attachment (3)

The researcher used the electronic learning achievement test that he designed (2013) attachment (3) and the key to correct it attachment (4). The total score of the test equal to the number of sentences (40) degree (Elsaid, 2013).

\section{5- The attitude scale towards the handball course:} attachment (5)

The researcher used the electronic attitude scale that he designed (2018), which was applied on the students of the second year of the Faculty of Physical Education University Mansoura university in the university year 2017/2018, where the scale included (30) phrase divided over three axes, the nature of the course the importance of studying the course, desire and enjoyment of the study of the course, with Fifth Likert Scale of which (17) positive Phrase, negative phrase (Elsaid, 2018).

Scientific coefficient of physical and skill tests, cognitive test and the attitude scale towards handball course:

\section{1 -The validity of the tests:}

The researcher found the validity of the tests used in the research using the validity of distinctive, by applying these tests to two groups, one of which is distinctive, they are the students of the specialty and the faculty team of handball and the second is indistinctive, that is the sample of the pilot study and the number (20) students of the second year of the Faculty of Physical Education University Mansoura, and after the application of the tests, The comparison was performed between the two groups, as shown in table (2). 
Table (2)

Differences significance between the two distinct and non-distinct groups in physical, skill tests, the cognitive test and the attitude scale towards the handball course $\mathrm{N} 1=\mathrm{N} 2=\mathbf{2 0}$

\begin{tabular}{|c|c|c|c|c|c|c|c|c|}
\hline & \multirow[t]{2}{*}{ Tests } & \multirow{2}{*}{$\begin{array}{c}\text { Unit of } \\
\text { measurement }\end{array}$} & \multicolumn{2}{|c|}{$\begin{array}{l}\text { Distinctive } \\
\text { group }\end{array}$} & \multicolumn{2}{|c|}{$\begin{array}{l}\text { Indistinctive } \\
\text { group }\end{array}$} & \multirow{2}{*}{$\begin{array}{c}\text { Mean } \\
\text { Difference }\end{array}$} & \multirow{2}{*}{$\begin{array}{c}\text { T- } \\
\text { value }\end{array}$} \\
\hline & & & Mean & \pm SD & Mean & \pm SD & & \\
\hline \multirow[b]{6}{*}{$\frac{\vec{J}}{\sqrt[0]{n}}$} & $\begin{array}{l}\text { Running (30) } \\
m \text { from the } \\
\text { high start }\end{array}$ & Second & 3.70 & 0.15 & 4.70 & 0.34 & 1 & $12.05 *$ \\
\hline & $\begin{array}{l}\text { Zigzag } \\
\text { running by } \\
\text { Barro }\end{array}$ & Second & 23.45 & 1.43 & 24.97 & 1.47 & -1.52 & $3.33^{*}$ \\
\hline & $\begin{array}{l}\text { Bend the } \\
\text { trunk in front } \\
\text { of the bottom } \\
\text { of the stand }\end{array}$ & Centimeter & 12.10 & 3.04 & 5.45 & 4.27 & 6.65 & $5.67 *$ \\
\hline & $\begin{array}{l}\text { Throw a } \\
\text { handball to } \\
\text { the furthest } \\
\text { distance }\end{array}$ & Meter & 26.66 & 1.83 & 21.65 & 3.56 & 5.01 & $5.60^{*}$ \\
\hline & $\begin{array}{l}\text { Vertical } \\
\text { jump }\end{array}$ & Centimeter & 46.90 & 3.51 & 38.35 & 4.55 & 8.55 & $6.66^{*}$ \\
\hline & $\begin{array}{ll}\text { Shooting } & \text { at } \\
\text { overlapping } \\
\text { rectangles }\end{array}$ & Degree & 19.10 & 2.07 & 11.30 & 1.95 & 7.80 & $12.25 *$ \\
\hline \multirow{6}{*}{$\frac{n}{\bar{n}}$} & $\begin{array}{l}\text { Passing and } \\
\text { receiving on the } \\
\text { wall } \\
\text { second }\end{array}$ & Number & 23.65 & 1.53 & 11.45 & 2.06 & 12.20 & $21.23 *$ \\
\hline & $\begin{array}{l}\text { Continuous } \\
\text { dribbling for } \\
\text { (30) Meter in a } \\
\text { zigzag direction }\end{array}$ & Second & 9.34 & 0.54 & 21.14 & 0.94 & -2.80 & $11.57 *$ \\
\hline & $\begin{array}{l}\text { The support } \\
\text { step overhand } \\
\text { shot }\end{array}$ & Degree & 5.20 & 0.70 & 1.55 & 0.89 & 3.65 & $14.48 *$ \\
\hline & $\begin{array}{l}\text { The accuracy } \\
\text { of the shot by } \\
\text { jumping high }\end{array}$ & Degree & 5.15 & 0.81 & 1.25 & 0.85 & 3.90 & $14.82 *$ \\
\hline & $\begin{array}{l}\text { Various defensive } \\
\text { moves }\end{array}$ & Number & 26.65 & 3.34 & 20.10 & 1.77 & 6.55 & 7.74* \\
\hline & $\begin{array}{l}\begin{array}{l}\text { One-way defense } \\
\text { blocking }\end{array} \\
\end{array}$ & Number & 3.10 & 0.31 & 1.75 & 0.64 & 1.35 & $8.52 *$ \\
\hline \multicolumn{2}{|c|}{ The cognitive test } & Degree & 34.35 & 1.42 & 10.50 & 1.61 & 23.85 & $49.69 *$ \\
\hline \multicolumn{2}{|c|}{ The attitude scale } & Degree & 135.25 & 4.18 & 59.10 & 3.55 & 76.15 & $62.09 *$ \\
\hline
\end{tabular}

* Significant $\mathrm{P}<0.05$ and Table value of "T" at (0.05) and freedom degree $(38)=2.02$

It is clear from table (2) that there are statistically significant differences between the two distinct and indistinct groups in favor of the distinctive group in all the tests under study, as the calculated "T" value is greater than it's 
scheduled value at the level of (0.05), which indicates the validity of these tests in measuring what they were set for.

\section{2- Reliability of tests:}

The researcher used the Test-Retest method through application on the pilot study sample consists of (20) students from the same research community and outside the basic sample, then reapply by a time difference (7) days of the first application on

\section{Table (3)}

The correlation coefficient between the first application and the second Application in physical, skill tests, the cognitive test and the attitude scale towards the handball course $\mathbf{N}=20$

\begin{tabular}{|c|c|c|c|c|c|c|c|}
\hline \multirow{2}{*}{\multicolumn{2}{|c|}{ Tests }} & \multirow{2}{*}{$\begin{array}{c}\text { Unit of } \\
\text { measurement }\end{array}$} & \multicolumn{2}{|c|}{ The first app } & \multicolumn{2}{|c|}{ The second app } & \multirow{2}{*}{$\begin{array}{c}\mathrm{R}- \\
\text { value }\end{array}$} \\
\hline & & & Mean & \pm SD & Mean & \pm SD & \\
\hline \multirow{6}{*}{ 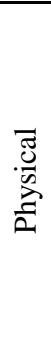 } & $\begin{array}{l}\text { Running (30) } \mathrm{m} \text { from } \\
\text { the high start }\end{array}$ & Second & 4.70 & 0.34 & 4.79 & 0.39 & $0.70 *$ \\
\hline & Zigzag running by Barro & Second & 24.97 & 1.47 & 24.92 & 1.65 & $0.77 *$ \\
\hline & $\begin{array}{l}\text { Bend the trunk in front of } \\
\text { the bottom of the stand }\end{array}$ & Centimeter & 5.45 & 4.27 & 5.90 & 4.38 & $0.95^{*}$ \\
\hline & $\begin{array}{l}\text { Throw a handball to } \\
\text { the furthest distance }\end{array}$ & Meter & 21.65 & 3.56 & 22.48 & 2.84 & $0.85^{*}$ \\
\hline & Vertical jump & Centimeter & 38.35 & 4.55 & 37.70 & 4.86 & $0.88^{*}$ \\
\hline & $\begin{array}{l}\text { Shooting at overlapping } \\
\text { rectangles }\end{array}$ & Degree & 11.30 & 1.95 & 10.80 & 1.36 & $0.82 *$ \\
\hline \multirow{6}{*}{$\frac{n}{\frac{n}{\sqrt{n}}}$} & $\begin{array}{l}\text { Passing and receiving on } \\
\text { the wall (30) second }\end{array}$ & Number & 11.45 & 2.06 & 11.80 & 1.44 & $0.64 *$ \\
\hline & $\begin{array}{l}\text { Continuous dribbling for } \\
\text { Meter in a zigzag direction }\end{array}$ & Second & 12.14 & 0.94 & 11.94 & 0.91 & $0.81 *$ \\
\hline & $\begin{array}{l}\text { The support step } \\
\text { overhand shot }\end{array}$ & Degree & 1.55 & 0.89 & 1.70 & 1.13 & $0.75^{*}$ \\
\hline & $\begin{array}{l}\text { The accuracy of the } \\
\text { shot by jumping high }\end{array}$ & Degree & 1.25 & 0.85 & 1.50 & 1.15 & $0.73 *$ \\
\hline & Various defensive moves & Number & 20.10 & 1.77 & 20.75 & 1.74 & $0.71 *$ \\
\hline & One-way defense blocking & Number & 1.75 & 0.64 & 1.95 & 0.60 & $0.78^{*}$ \\
\hline \multicolumn{2}{|c|}{ The cognitive test } & Degree & 10.50 & 1.61 & 10.85 & 1.39 & $0.86^{*}$ \\
\hline \multicolumn{2}{|c|}{ The attitude scale } & Degree & 59.10 & 3.55 & 59.85 & 2.68 & $0.84^{*}$ \\
\hline
\end{tabular}

* Significant $\mathrm{P}<0.05$ and Table value of "R" at $(0.05)=0.44$

Table (3) shows a strong positive correlation between the same group and at the same time to standardize the measurement conditions as much as possible, then the coefficient of correlation was calculated to ensure the reliability of physical, skill tests, the cognitive test and the attitude scale towards the course, the first application was on Tuesday, 4/12/2018 and the second application was on Tuesday, 11/12/2018 as shown in table (3). 
skill tests, cognitive test and attitude scale towards the course, with the values of the calculated correlation coefficient ranging from (0.64:0.95) and all greater than the scheduled "R" value at the level of (0.05), indicating the reliability of these tests.

Second: Flipped learning strategy:

The researcher activated the electronic handball course, which was designed in the 2017/18 university year, using Moodle system and loaded on server University of Mansoura through the e-learning unit of the university and included a group of educational units, sources, activities and a system of evaluation to follow the progress of students.

The educational content was provided within the strategy of flipped learning for students at home before they come to the lecture by entering the course of the lecture to see the topic of the lecture, which combines texts, images, drawings and educational videos, and during the lecture the new content is strengthened by the practical applications and discussions of students under the supervision of the teacher to become the full lecture time for active learning, where students find sufficient opportunities to deepen the educational content. (AlSharman, 2015, p. 160-161)
Time distribution of the content of the educational units of the experimental group: attachment (6)

The handball course was taught using the flipped learning strategy during (12) weeks with two lectures per week, one theoretical and the other practical, time of each one is (120) minutes in total (24) lecture, (12) theoretical lectures, and (12) practical lectures according to the course's description of the basic principles for handball group games, during the second semester of the academic year 2018/2019 from $9 / 2 / 2019$ until $2 / 5 / 2019$ as described by the teacher's guide to teach the basic principles of handball group games according to the flipped learning strategy attachment (6).

\section{Pilot study:}

It was conducted from $4 / 12 / 2018$ to $11 / 12 / 2018$ with the aim of applying the physical abilities tests, skill tests, cognitive test and attitude scale towards the course under research to identify validity and reliability on a sample of (20) students of the second year of the Faculty of Sports Education of Mansoura University, and the results were the validity and reliability of physical tests, skill tests, cognitive test and the attitude scale to apply the basic study sample. 
Basic study:

Pre- test measurements:

After confirming the scientific coefficient (validity reliability) of the tests used in the research, the researcher conducted pretest measurements of the study variables on the experimental and control groups of (94) students in growth rates, physical abilities, skill tests, cognitive achievement test and the attitude scale towards the handball course, from Tuesday, $18 / 12 / 2018$ to Thursday 20/12/2018.

\section{Normal distribution of the research variables:}

The researcher verified the normal distribution of the research sample in the variables (growth rates, physical abilities, skill tests, cognitive achievement test and attitude scale towards handball course) by calculating the coefficients of skewness and kurtosis for all the measurements used in the research to ensure that the basic research sample is moderately distributed, as shown in table (4):

\section{Table (4)}

\section{The arithmetic mean, standard deviation, skewness coefficient} and kurtosis Coefficient in the descriptive, physical, skillful, cognitive tests and attitude scale towards the course $N=114$

\begin{tabular}{|c|c|c|c|c|c|c|}
\hline \multicolumn{2}{|r|}{ Measurements } & $\begin{array}{c}\text { Unit of } \\
\text { Measurement }\end{array}$ & $\begin{array}{c}\text { Arithmetic } \\
\text { mean }\end{array}$ & $\begin{array}{l}\text { Standard } \\
\text { deviation }\end{array}$ & $\begin{array}{l}\text { Skewness } \\
\text { coefficient }\end{array}$ & $\begin{array}{c}\text { Kurtosis } \\
\text { coefficient }\end{array}$ \\
\hline \multirow{3}{*}{ 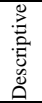 } & Age & year & 19.66 & 0.36 & -0.38 & -1.18 \\
\hline & Height & $\mathrm{Cm}$ & 174.60 & 3.42 & 0.31 & -0.48 \\
\hline & Weight & $\mathrm{kg}$ & 70.90 & 6.48 & 0.30 & -0.59 \\
\hline \multirow{6}{*}{ 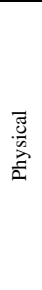 } & $\begin{array}{l}\text { Running (30) } \mathrm{m} \text { from } \\
\text { the high start }\end{array}$ & Second & 4.67 & 0.41 & 0.33 & 0.41 \\
\hline & Zigzag running by Barro & Second & 24.99 & 1.94 & 0.16 & 0.29 \\
\hline & $\begin{array}{l}\text { Bend the trunk in front of } \\
\text { the bottom of the stand }\end{array}$ & $\mathrm{Cm}$ & 5.32 & 5.33 & -0.42 & 0.84 \\
\hline & $\begin{array}{l}\text { Throw a handball to } \\
\text { the furthest distance }\end{array}$ & Meter & 22.46 & 3.09 & 0.05 & 0.33 \\
\hline & Vertical jump & $\mathrm{Cm}$ & 38.46 & 5.30 & 0.30 & 0.81 \\
\hline & Shooting at overlapping rectangles & Degree & 10.58 & 3.50 & -0.74 & 0.44 \\
\hline \multirow{6}{*}{$\frac{a}{\bar{n}}$} & $\begin{array}{l}\text { Passing and receiving } \\
\text { on the wall (30) second }\end{array}$ & Number & 11.38 & 2.26 & -0.32 & -0.09 \\
\hline & $\begin{array}{l}\text { Continuous dribbling for (30) } \\
\text { Meter in a zigzag direction }\end{array}$ & Second & 12.74 & 1.27 & 0.15 & -0.63 \\
\hline & The support step overhand shot & Degree & 1.70 & 0.94 & 0.18 & -0.32 \\
\hline & $\begin{array}{l}\text { The accuracy of the } \\
\text { shot by jumping high }\end{array}$ & Degree & 1.39 & 0.90 & 0.25 & -0.31 \\
\hline & Various defensive moves & Number & 19.22 & 2.06 & 0.20 & -0.50 \\
\hline & One-way defense blocking & Number & 1.73 & 0.60 & 0.18 & -0.54 \\
\hline \multicolumn{2}{|c|}{ The cognitive test } & Degree & 10.34 & 2.58 & -0.14 & -0.34 \\
\hline \multicolumn{2}{|c|}{ The attitude scale } & Degree & 59.05 & 6.97 & -0.17 & 0.15 \\
\hline
\end{tabular}

The significance limit of the skewness coefficient at the level $(0.05)=0.45$

The significance limit of the kurtosis coefficient at the level $(0.05)=0.90$ 
Table (4) shows that the values of Skewness coefficient for descriptive, physical, skillful measurements, cognitive tests and the attitude scale towards the course ranged from (-0.74: 0.33) and it is less than the significance limit of the skewness coefficient. The value of kurtosis coefficient ranged from (-1.18: 0.84) and it is less than the significance limit of the kurtosis coefficient that refer to moderation of the sample distribution in these variables under research.

Homogeneity of the two research groups:

The researcher performed homogeneity between the two groups (experimental and control) Before applying the search in the physical and skillful tests, cognitive tests and the attitude scale towards the handball course under research, as shown in table (5):

\section{Table (5)}

The arithmetic mean, standard deviation and sample homogeneity in variables under research $\mathrm{N} 1=\mathrm{N} 2=47$

\begin{tabular}{|c|c|c|c|c|c|c|c|c|}
\hline & \multirow[t]{2}{*}{ Tests } & \multirow{2}{*}{$\begin{array}{c}\text { Unit of } \\
\text { measurement }\end{array}$} & \multicolumn{2}{|c|}{$\begin{array}{l}\text { Experimental } \\
\text { Group }\end{array}$} & \multicolumn{2}{|c|}{$\begin{array}{c}\text { Control } \\
\text { group }\end{array}$} & \multicolumn{2}{|c|}{$\begin{array}{l}\text { Levene's } \\
\text { Test }\end{array}$} \\
\hline & & & Mean & \pm SD & Mean & \pm SD & $\mathbf{F}$ & Sig. \\
\hline \multirow{7}{*}{ 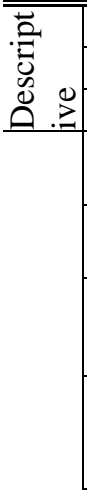 } & Age & year & 19.63 & 0.39 & 19.66 & 0.34 & 2.03 & 0.16 \\
\hline & Height & $\mathrm{Cm}$ & 174.77 & 3.50 & 174.40 & 3.13 & 0.75 & 0.39 \\
\hline & Weight & $\mathrm{kg}$ & 71.06 & 6.59 & 70.89 & 6.97 & 0.20 & 0.65 \\
\hline & $\begin{array}{l}\text { Running (30) } \\
m \text { from the } \\
\text { high start }\end{array}$ & Second & 4.68 & 0.44 & 4.63 & 0.41 & 0.03 & 0.87 \\
\hline & $\begin{array}{l}\text { Zigzag } \\
\text { running by } \\
\text { Barro }\end{array}$ & Second & 25.31 & 1.99 & 24.67 & 2.05 & 0.27 & 0.60 \\
\hline & $\begin{array}{l}\text { Bend the } \\
\text { trunk in front } \\
\text { of the bottom } \\
\text { of the stand }\end{array}$ & Centimeter & 5.40 & 5.47 & 5.17 & 5.68 & 0.02 & 0.88 \\
\hline & $\begin{array}{l}\text { Throw a } \\
\text { handball to } \\
\text { the furthest } \\
\text { distance }\end{array}$ & Meter & 22.80 & 3.18 & 22.46 & 2.77 & 0.18 & 0.68 \\
\hline \multirow{2}{*}{$\frac{\overrightarrow{0}}{\frac{0}{n}}$} & Vertical jump & Centimeter & 38.15 & 4.72 & 38.81 & 6.17 & 2.10 & 0.15 \\
\hline & $\begin{array}{l}\text { Shooting at } \\
\text { overlapping } \\
\text { rectangles }\end{array}$ & Degree & 10.72 & 3.51 & 10.13 & 3.97 & 1.30 & 0.26 \\
\hline$\frac{n}{\overline{\frac{n}{n}}}$ & $\begin{array}{l}\text { Passing and } \\
\text { receiving } \\
\text { on the wall } \\
\text { (30) second }\end{array}$ & Number & 11.53 & 2.22 & 11.19 & 2.40 & 0.60 & 0.44 \\
\hline
\end{tabular}


Follow Table (5)

The arithmetic mean, standard deviation and sample

homogeneity in variables under research $\mathrm{N} 1=\mathrm{N} 2=47$

\begin{tabular}{|c|c|c|c|c|c|c|c|}
\hline \multirow[t]{2}{*}{ Tests } & \multirow{2}{*}{$\begin{array}{c}\text { Unit of } \\
\text { measurement }\end{array}$} & \multicolumn{2}{|c|}{$\begin{array}{c}\text { Experimental } \\
\text { Group }\end{array}$} & \multicolumn{2}{|c|}{$\begin{array}{c}\text { Control } \\
\text { group }\end{array}$} & \multicolumn{2}{|c|}{$\begin{array}{c}\text { Levene's } \\
\text { Test }\end{array}$} \\
\hline & & Mean & \pm SD & Mean & \pm SD & $\mathbf{F}$ & Sig. \\
\hline $\begin{array}{l}\text { Continuous } \\
\text { dribbling for } \\
\text { (30) Meter in } \\
\text { a zigzag } \\
\text { direction }\end{array}$ & Second & 12.76 & 1.31 & 12.98 & 1.28 & 0.09 & 0.76 \\
\hline $\begin{array}{l}\text { The support step } \\
\text { overhand shot }\end{array}$ & Degree & 1.60 & 1.01 & 1.87 & 0.88 & 1.37 & 0.25 \\
\hline $\begin{array}{l}\text { The accuracy } \\
\text { of the shot by } \\
\text { jumping high }\end{array}$ & Degree & 1.45 & 0.90 & 1.40 & 0.92 & 0.06 & 0.81 \\
\hline $\begin{array}{l}\text { Various } \\
\text { defensive } \\
\text { moves }\end{array}$ & Number & 18.91 & 1.99 & 19.15 & 2.19 & 0.59 & 0.44 \\
\hline \begin{tabular}{|l|}
$\begin{array}{l}\text { One-way } \\
\text { defense } \\
\text { blocking }\end{array}$ \\
\end{tabular} & Number & 1.74 & 0.61 & 1.70 & 0.59 & 0.001 & 0.99 \\
\hline The cognitive test & Degree & 10.21 & 2.87 & 10.40 & 2.65 & 0.18 & 0.68 \\
\hline The attitude scale & Degree & 58.36 & 8.27 & 59.72 & 6.70 & 2.38 & 0.13 \\
\hline
\end{tabular}

Table (5) shows that the homogeneity of the experimental and control groups in all the variables under research. The Levene's test ranged from (0.001: 2.38) with significance levels ranged from (0.13: 0.99) as it is greater than the level $(0.05)$ that refers to the homogeneity of the two groups in these variables.

\section{2- Carrying out the study:}

The researcher taught the two research groups in the second semester of the academic year (2018/2019) during the period from $9 / 2 / 2019$ to $2 / 5 / 2019$ and for a period of (12) weeks with two lectures per week, one theoretical inside faculty halls and the other practical inside sports hall of the Olympic village Mansoura university stadium time of each one is (120) minutes as follows:

- The control group was taught using the traditional method (presentation, explanation and model performance).

- The experimental group was taught using an flipped learning strategy, where students were introduced how to enter the electronic handball course at the beginning of the second semester, and before the lecture is determined the part to be taught to students to see the content of the lesson from educational sources and videos on the page of the 
course at home, and asks the researcher students to identify the difficult parts to clarify them during the lesson, during the lecture discussions and applications are conducted individually and in cooperative groups and the researcher provides guidance, guidance and immediate feedback to correct errors attachment (6).

3- post-test measurements:

After completing the specified duration of the application, the researcher carried out the post-test measurements of both experimental and control groups in the skill tests, The cognitive test and attitude scale towards the course, on Saturday, 4/5/2019 for the experimental group, Sunday $5 / 5 / 2019$ for the control group and all measurements were carried out as conducted in the pre-test measurements.

\section{4- Data collection and scheduling:}

The researcher collected, scheduled and statistically processed the data after applying the study.

\section{5 -Statistical analysis:}

The data were statistically processed using the
Social Science Statistical Package Program (SPSS) to calculate the statistical coefficients used by the research: mean, standard deviation, skewness coefficient, kurtosis coefficient, (t) test for independent and paired samples, Pearson Simple Correlation Coefficient and improvement ratio.

\section{Showing and discussing research results:}

Within the limits of the research plan and procedures, the researcher reached through the statistical treatments used for a set of results in the light of the research assignments, the researcher presented them in a table and then interpreted and discussed.

\section{First: Showing results of the first hypothesis:}

The researcher calculated the significance of the differences and improvement ratios between pre and post measurements of the control group in the skill tests, cognitive test and attitude scale towards the course under research, as shown in the table (6).

Table (6)

Assiut Journal For Sport Science Arts 
Differences significance between pre and post tests for the control group in skill tests, cognitive test and the attitude scale towards the course $\mathrm{N}=47$

\begin{tabular}{|c|c|c|c|c|c|c|c|c|}
\hline & \multirow{2}{*}{ Tests } & \multicolumn{2}{|c|}{ Pre-test } & \multicolumn{2}{|c|}{ Post-test } & \multirow{2}{*}{$\begin{array}{l}\text { Mean } \\
\text { Differ- } \\
\text { ence }\end{array}$} & \multirow{2}{*}{$\begin{array}{c}\text { T- } \\
\text { value }\end{array}$} & \multirow{2}{*}{$\begin{array}{c}\text { Improve- } \\
\text { ment } \\
\text { ratio } \%\end{array}$} \\
\hline & & Mean & \pm SD & Mean & \pm SD & & & \\
\hline \multirow{6}{*}{$\frac{n}{=\frac{\pi}{n}}$} & $\begin{array}{l}\text { Passing and } \\
\text { receiving on the wall } \\
\text { (30) second }\end{array}$ & 11.19 & 2.40 & 17.28 & 2.20 & -6.09 & $17.98 *$ & 54.42 \\
\hline & $\begin{array}{l}\text { Continuous } \\
\text { dribbling for (30) } \\
\text { Meter in a zigzag } \\
\text { direction }\end{array}$ & 12.98 & 1.28 & 11.15 & 1.46 & 1.83 & $9.68 *$ & 14.1 \\
\hline & $\begin{array}{ll}\begin{array}{l}\text { The support } \\
\text { overhand shot }\end{array} & \\
\end{array}$ & 1.87 & 0.88 & 3.53 & 0.95 & -1.66 & $10.08 *$ & 88.77 \\
\hline & $\begin{array}{l}\text { The accuracy of the } \\
\text { shot by jumping } \\
\text { high }\end{array}$ & 1.40 & 0.92 & 2.94 & 0.99 & -1.54 & $12.27 *$ & 110 \\
\hline & $\begin{array}{l}\text { Various defensive } \\
\text { moves }\end{array}$ & 19.15 & 2.19 & 24.36 & 1.71 & -5.21 & $18.82 *$ & 27.21 \\
\hline & $\begin{array}{ll}\text { One-way } & \text { defense } \\
\text { blocking } & \\
\end{array}$ & 1.70 & 0.59 & 2.26 & 0.71 & -0.56 & $5.53 *$ & 32.94 \\
\hline \multicolumn{2}{|c|}{ The cognitive test } & 10.40 & 2.65 & 24.13 & 2.48 & -1.37 & $28.79 *$ & 132.01 \\
\hline \multicolumn{2}{|c|}{ The attitude scale } & 59.72 & 6.70 & 84.98 & 5.20 & -25.26 & $24.56^{*}$ & 42.30 \\
\hline
\end{tabular}

*Significant at the $(0.05)$ level.

Table value of " $T$ " at $(0.05)$ and freedom degree $(46)=2.02$

Table

(6)

statistically

significant

differences between both pre and post tests for the control group in the skill tests, cognitive test, and the attitude scale towards the course under research in favor of the posttest where the calculated "T" values ranged from (5.29: 28.79) which are values higher than the scheduled " $\mathrm{T}$ " at the level of significance (0.05), confirming the improvement of the control group in these tests under research.

\section{Second: Showing results of} the second hypothesis:

The researcher calculated the significance of the differences and improvement ratios between pre and post measurements of the experimental group in skill tests, cognitive test and the attitude scale towards the course under research, as shown in the table (7). 
Table (7)

Differences significance between pre and post tests for the experimental group in skill tests, cognitive test and the attitude scale towards the course $\mathrm{N}=47$

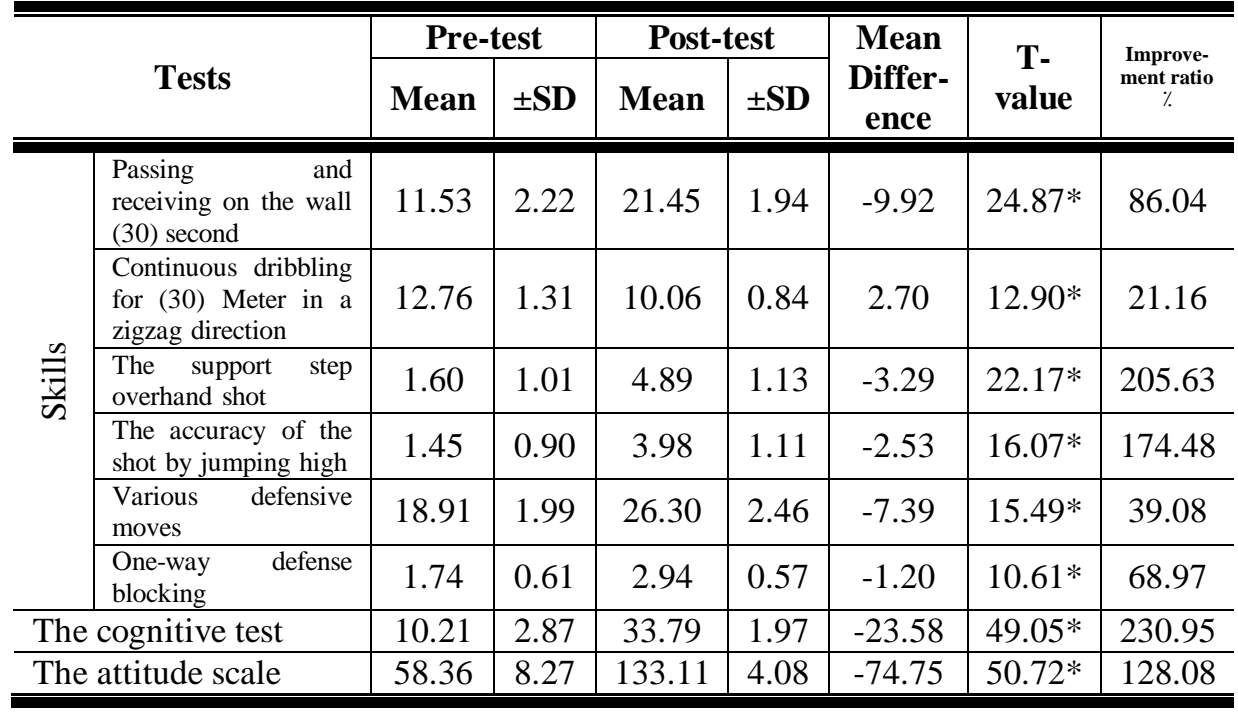

*Significant at the (0.05) level.

Table value of "T" at (0.05) and freedom degree $(46)=2.02$

Table (7) shows

statistically significant differences between both pre and post tests for the experimental group in the skill tests, cognitive test, and the attitude scale towards the course under research in favor of the post-test where the calculated " $\mathrm{T}$ " values ranged from (11.44: 50.72) which are values higher than the scheduled "T" at the level of significance (0.05), confirming the improvement of the experimental group in these tests under research.

\section{Third: Showing results of the} third hypothesis:

The researcher calculated the significance of the differences and the rate of improvement between the two post-tests of both experimental and control groups in the skill tests, cognitive test and the attitude scale towards the course under research, as shown in the table (8). 
Table (8)

Differences significance between post-tests for experimental and control group in in skill tests, cognitive test and the attitude scale towards the course $\mathrm{N} 1=\mathrm{N} 2=47$

\begin{tabular}{|c|c|c|c|c|c|c|c|}
\hline \multirow{2}{*}{\multicolumn{2}{|c|}{ Tests }} & \multicolumn{2}{|c|}{$\begin{array}{c}\text { Experimental } \\
\text { Group }\end{array}$} & \multicolumn{2}{|c|}{$\begin{array}{l}\text { Control } \\
\text { group }\end{array}$} & \multirow{2}{*}{$\begin{array}{c}\text { Mean } \\
\text { Difference }\end{array}$} & \multirow{2}{*}{$\begin{array}{c}\text { T- } \\
\text { value }\end{array}$} \\
\hline & & Mean & \pm SD & Mean & \pm SD & & \\
\hline \multirow{6}{*}{$\frac{n}{\frac{\pi}{n}}$} & $\begin{array}{l}\text { Passing and receiving on } \\
\text { the wall (30) second }\end{array}$ & 21.45 & 1.94 & 17.28 & 2.20 & 4.17 & $9.73^{*}$ \\
\hline & $\begin{array}{l}\text { Continuous dribbling } \\
\text { for }(30) \text { Meter in a } \\
\text { zigzag direction }\end{array}$ & 10.06 & 0.84 & 11.15 & 1.46 & -1.09 & $4.42 *$ \\
\hline & $\begin{array}{ll}\begin{array}{l}\text { The support } \\
\text { overhand shot }\end{array} & \text { step } \\
\end{array}$ & 4.89 & 1.13 & 3.53 & 0.95 & 1.36 & $6.33^{*}$ \\
\hline & $\begin{array}{l}\text { The accuracy of the } \\
\text { shot by jumping high }\end{array}$ & 3.98 & 1.11 & 2.94 & 0.99 & 1.04 & $4.81 *$ \\
\hline & Various defensive moves & 26.30 & 2.46 & 24.36 & 1.71 & 1.94 & $4.43 *$ \\
\hline & $\begin{array}{ll}\begin{array}{l}\text { One-way } \\
\text { blocking }\end{array} & \text { defense } \\
\end{array}$ & 2.94 & 0.57 & 2.26 & 0.71 & 0.68 & $5.15^{*}$ \\
\hline \multicolumn{2}{|c|}{ The cognitive test } & 33.79 & 1.97 & 24.13 & 2.48 & 9.66 & $20.92 *$ \\
\hline \multicolumn{2}{|c|}{ The attitude scale } & 133.11 & 4.08 & 84.98 & 5.20 & 48.13 & $49.92 *$ \\
\hline
\end{tabular}

*Significant at the (0.05) level.

Table value of "T" at (0.05) and freedom degree $(92)=1.99$

Table (8) shows

statistically significant differences between the two post-tests for the experimental and control groups in in skill tests, cognitive test and the attitude scale towards the course under research for the experimental group where the calculated "T" values ranged from (4.42: 49.92) which are higher than the table value of the T" at the level of significance (0.05), confirming the improvement of the experimental group in these tests under research to a higher degree than the control group.

Discussion of the results:
First: Discussing results of the first hypothesis:

Table

(6)

shows statistically significant differences between both pre and post tests for the control group in the skill tests, cognitive test, and the attitude scale towards the course under research in favor of the posttest where the calculated "T" values ranged from (5.29: 28.79) which are values higher than the scheduled " $\mathrm{T}$ " at the level of significance (0.05), confirming the improvement of the control group in these tests under research.

The researcher interpreted that the Assiut Journal For Sport Science Arts 
improvement in the post test for the control group to the exposure of students in educational experiences as verbal explanation, model performance and feedback to correct errors by the teacher, practice, application and repetition on the part of students, which led to improved learning outcomes for them.

This is in the same line with study findings of Kurdi (2014), El-Shamy (2015), Abdul Razaq (2016), Abdul Latif (2016) and Heredia (2015), they reported that the traditional method had a positive impact on improving cognitive, skill and emotional learning outcomes.

El-Hayek (2018, 79) emphasizes that teaching using the traditional method (explanation and model performance) leads to the achievement of learning outcomes and familiarity with educational content and reach the required level of performance, the teacher explains and presents the model and then assigns students to perform tasks, assignments and training according to his instructions and he has to provide feedback and clarify any inquiry to the students.

Thus, the validity of the first hypothesis, which says that: There are statistically significant differences between the means of pre-test and posttest measurements of the control group in handball learning outcomes for students of the Faculty of Physical Education University of Mansoura in favor of post-test measurement.

Second: Discussing results of the second hypothesis:

Table

shows statistically significant differences between both pre and post tests for the experimental group in the skill tests, cognitive test, and the attitude scale towards the course under research in favor of the post-test where the calculated "T" values ranged from (11.44: 50.72) which are values higher than the scheduled "T" at the level of significance (0.05), confirming the improvement of the experimental group in these tests under research.

The researcher interpreted this to the fact that the strategy of flipped learning makes the learner watch lectures prepared by the 
teacher at home and its models, images, texts, explanations, educational videos and short electronic tests supported by immediate feedback, to become ready for applications and practical trainings with his colleagues and under the supervision of the teacher and the teacher's discussion in all difficulties he faced at home, as the use of more than one sense in learning makes it more enjoyable and interesting, which led to improved level of knowledge and knowledge achievement and increased enthusiasm and interaction during the course.

Both Al-Drawiish and Abdul Alim (2017, 140-141) point out that using flipped learning strategy helps learners acquire knowledge, information and skills by repeating educational content more than once and easily refers to it and makes the learner the focus of The educational process and increases its activity and effectiveness at home and inside the classroom, where the learner interacts with the videos or any educational media prepared by the teacher, as well as the learner is a positive participant for his colleagues inside the classroom in the implementation of tasks and activities prepared by the teacher to achieve the educational goals of the lesson Under the supervision and guidance of the teacher.

This finding is consistent with the results of the study of Abdul Zahir (2016), Zaghloul (2017), Mahmoud (2018), Amin and Balbas (2018), Alsobaie (2018), Callahan (2018), Albishi (2018) and Snyder (2019), whose results indicated that the flipped learning strategy is a new, effective and more attractive strategy, providing time for activities, practices and skills applications and enhancing a better understanding of students.

El Miedany (2019, 290291) emphasizes that employing flipped learning strategy makes educational content more attractive and increases the active participation of students and enables the teacher to move from one student to another to provide all the individual support a student needs to clarify or instant feedback and error correction, where students watch videos of recorded lectures or read any 
material related to the next day's online learning position at home with the possibility of re-watching and repeating and reviewing materials according to its own speed, and students make use of the lecture time For active learning tasks, activities, discussions and applications either individually or in groups under the supervision of the teacher.

Thus, the validity of the second hypothesis, which says that: There are statistically significant differences between the means of pre-test and posttest measurements of the experimental group in handball learning outcomes for students of the Faculty of Physical Education University of Mansoura in favor of post-test measurement.

Third: Discussing results of the third hypothesis:

Table (8) shows statistically significant differences between the two post-tests for the experimental and control groups in in skill tests, cognitive test and the attitude scale towards the course under research for the experimental group, where the calculated "T" values ranged from (4.42: 49.92) which are higher than the table value of the $\mathrm{T}^{\prime \prime}$ at the level of significance (0.05), confirming the improvement of the experimental group in these tests under research to a higher degree than the control group.

This is due to the fact that the flipped learning strategy helped to create an interactive learning environment, increased the demand of students and their enthusiasm to study the modules of the course in a new way by presenting the course in an electronic form including educational videos, electronic tests and discussion forums for students to see at home before the lecture time, to invest lecture time in training, practical applications, discussions and activities to apply and implement what was learned outside the lecture under the supervision of the teacher and correct mistakes and provide immediate feedback, which contributed to improving learning outcomes in handball.

This finding is consistent with the results of the study of Prepose (2015), Abdul Latif (2016), Dusenbury (2016), ElShamy (2017), Zaghloul (2017), Mahmoud (2018), Amin and Balbas (2018), 
Maddox (2018) and Flick (2019), whose results indicated that the flipped learning strategy is an effective strategy in promoting the success and satisfaction of students, improving their achievement and developing their skills.

Abdul Zahir (2016, 193) emphasizes that the flipped learning strategy ensures the optimal use of lecture time in discussion, dialogue and training activities, makes the learner responsible for his learning and increases his motivation to learn and makes the learning process enjoyable for students to use modern techniques in the educational process and provides opportunities for interaction and communication between students and teachers inside and outside the classroom, and gives students an incentive to prepare lessons and prepare before lecture time.

This is consistent with $\operatorname{Arcos}(2014,2)$ that the flipped learning strategy enables students to replay the video several times, so that they can understand new concepts, and enable them to speed up the clip to overcome the parts that have been absorbed, taking into account the individual differences between students and disappearing the element of boredom, and replacing it with the element of suspense and enjoyment of learning, as well as providing a mechanism to evaluate the absorption of students, the tests and short assignments that help the teacher to recognize the weaknesses and strengths in their absorption of the content.

This result differs with the result of the Heredia study (2015), whose results indicated that there are no statistically significant differences between the degrees of the experimental and control groups in educational achievement, as well as with the result of the Osman study (2016, 39-41) which showed that the achievement of the experimental group was lower than the control group and that there was a negative trend of the experimental group towards flipped learning because they did not have adequate training on the use of technology such as computers, the Internet, and multimedia content.

Thus, the validity of the third hypothesis, which says: There are statistically significant differences between the means of the two post-test

\section{Assiut Journal For Sport Science Arts}


measurements of the control and experimental groups in handball learning outcomes for students of the Faculty of Physical Education university of Mansoura in favor of the post-test measurement of the experimental group.

\section{Conclusions:}

1- The use of the flipped learning strategy affected positively on the learning outcomes in handball for the students of the second year at the Faculty of Physical Education University of Mansoura.

2- The use of the traditional method affected positively on the learning outcomes in handball for the students of the second year at the Faculty of Physical Education University of Mansoura.

3- The flipped learning strategy outweighs the traditional method of improving the learning outcomes in handball for the students of the second year at the Faculty of Physical Education University of Mansoura.

Research recommendations:

1- Using the flipped learning strategy in teaching handball skills for the students of the second year at the Faculty of
Physical Education University of Mansoura.

2- Expanding the use of the flipped learning strategy in teaching other courses to students of the Faculty of Physical Education University Mansoura University, to maximize the benefit of learning time .

3- Employing the possibilities of the e-learning management system available at the elearning unit of Mansoura University in the teaching of courses and including them for the strategy of flipped learning.

\section{References}

1- Abdul Latif, S. M. (2016). The impact of the use of the flipped learning strategy on the development of the cognitive aspect and creative thinking skills in the study of physical education among students of the Faculty of Physical Education, Tanta University. Scientific Journal of Physical Education and Sports Sciences, Faculty of Sports Education for Boys, Helwan University, No. (77), (pp.) 67-116.

2- Abdul Razaq, N. K. (2016). A proposed program to learn some offensive skills in handball using educational modules and its impact on learning outcomes for 
students of the Faculty of Physical Education, University of Anbar in Iraq. Ph.D. thesis. faculty of physical education for girls, Alexandria University.

3- Abdul Zahir, A. A. (2016). The effectiveness of a suggested program based on flipped learning on developing new valley faculty of education first year mathematics department student achievement, learning attaining and attitude towards it. Journal of Mathematics Education, Egyptian Society of Mathematics Education, Vol. 19, No. (10), (pp.) 161-193.

4- Albishi, S. (2018). The use of flipped classroom instructional model in teaching mathematics in higher education: Instructors' perspectives in Saudi (Doctoral dissertation). The College of Graduate and Professional Studies, Indiana State University.

5- Al-Drawiish, A. B and Abdul Alim, R.A. (2017). Technological innovations and educational modernization, Cairo, Dar Elfeker Elaraby.

6- Al-Kahaili, I. S. (2015). The effectiveness of flipped classes in education. Medina, Dar alZaman.

7- Al-Sharman, A. A. (2015). Built-in learning and inverse learning. Amman, Dar alMarcha.

8- Alsobaie, M. F. (2018). Effective teaching and learning: Flipped learning in the classroom (Doctoral dissertation). the Graduate College, Western Michigan University.

9- Amin, B. A and Balbas, H. M. (2018). Effect of using Reverse Thinking Strategy (Note - Reflect - Explain) in Learning of Free Throw and Lay-up Performance in Basketball, Journal of Arts, Literature, Humanities and Sociology, Emirates College of Educational Sciences, No, (30), (pp.) 253-265.

10-Arcos, B. (2014). Flipping with OER: K12 teachers' views of the impact of open practices on students. In: OCWC Global 2014: Open Education for a Multicultural World, 23-25 Apr 2014, Ljubljana, Slovenia.

11- Callahan, J. (2018). The Efficacy of problem-based teaching strategies on facilitating student engagement in a flipped learning module (Doctoral dissertation). School of Education, Capella University.

12- Darwish, K. A, Morsy, K. $S$ and Abo Zaed, E. A. (2002). 
measurements, evaluation, analysis the match in handball, theories -applications, Alketab center for publishing, Cairo.

13- Dusenbury, M. J. (2016). The effects of flipped learning on critical thinking disposition among undergraduate college students (Doctoral dissertation). Graduate Faculty, University of North Dakota.

14- El Miedany, Y. (2019). Rheumatology Teaching The Art and Science of Medical Education, Springer, Cham. https://doi.org/10.1007/978-3319-98213-7

15- El-Hayek, S. K. (2018). Contemporary curricula and strategies in the teaching of sports education. Oman.

16- Elsaid, T. (2013). Setting up an electronic cognitive test in handball for faculty of sports education students, Mansoura university, The 11th International Conference for Physical Education and Movement Science- Sport in Theory\& Practice, Alexandria.

17- Elsaid, T. M. (2020). The Effectiveness of an Electronic course in handball to develop the cognitive achievement and the attitude towards the course for faculty of physical education students Mansoura University. Scientific Journal of Sports Science Applications, Faculty of Sports Education for Boys. University of Alexandria, Vol, (6), No. (104), (PP.) 230- 250.

18- El-Shamy, E. A. (2017). Effect of Flipped Electronic Course on the Teaching Performance and Reflective Thinking Skills of the Teacher Female Students at the Faculty of Home Economics, Al-Azhar University. 3rd International Conference: The Future of Teacher Preparation and Development in the Arab World, Faculty of Education, University of October 6, Vol (5).

19- El-Shamy, N. M. (2015). Effectiveness of Technical program for learning Team Plans in Handball on the Cognitive achievement and Tactical Performance for students at the Faculty of Physical Education, doctoral thesis, faculty of physical education for girls, Alexandria University.

20- Flick, A. (2019). The Effects of Flipped Learning in the Sixth-Grade Mathematics Classroom (Doctoral dissertation). Faculty of the Graduate School, Missouri Baptist University. 
21- Heredia, K. (2015). The Effects of the Flipped Classroom Model on Student Academic Growth in Flipped and Traditional Community College Classrooms (Doctoral dissertation). College of Education, Aurora University.

22- Ismaeel, $K$. A and Hasaneen, M. S. (2001). Modern handball quartet, what it is audits educational dimensions- measurement and evaluation principles-physical education, Alketab center for publishing, Cairo, 2001.

23- Ismaeel, $K$. A and Hasaneen, M. S. (2002). Modern handball quartet, technical skills, level of performance observation, pt. (2), Alketab center for publishing, Cairo.

24- Kurdi, B. O. (2014). The effectiveness of using the Reciprocal style to learn some offensive skills in handball for eighth - graders basic province of Kurdistan -Iraq, Master Thesis, faculty of physical education for girls, Alexandria University.

25- Maddox, D. (2018). Quasi- Experimental study on the effectiveness of flipped learning for middle school students' science achievement
(Doctoral dissertation). Morgan State University.

26- Mahmoud, G. O. (2018). The effect of using the flipped learning method on improving the teaching skills of a female teacher in fencing. Assiut Journal of Science and Arts of Physical Education, Faculty of Physical Education, University of Assiut, No. (47), (pp.) 109125.

27- Osman, H. A. (2016): The effect of using flipped learning strategy on the achievement of 7th grade female students in subject science and their attitudes towards learning. Master's thesis. Faculty of Education, Yarmouk University. Jordan.

28- Prepose, L. S. (2015). Online, flipped, and traditional instruction: A comparison of student performance in higher education (Doctoral dissertation). faculty of USC Rossier school of education, university of southern California.

29- Rashid, T. S. (2017). The effectiveness of a science program based on flipped classes for achievement development and some creative solution skills for problems and motivation for achievement among talented students with learning disabilities in the fourth grade of primary school. 
Educational Sciences, Graduate School of Education, Cairo University, No. (2), Vol. (25), (pp.)152-196.

30- Roehling, P.V. (2018). Flipping the College Classroom An Evidence-Based Guide, Palgrave Pivot, Cham. https://doi.org/10.1007/978-3319-69392-7.

31- Snyder, N. C. (2019). Using expert opinion to define flipped learning and characterize its impact on learning (Doctoral dissertation).
Moravian College, Fordham University, New York.

32- Zaghloul, N. H. (2017). The effectiveness of the flipped grade strategy at the level of learning some basic skills in gymnastics for fifth graders from basic education in the UAE. Assiut Journal of Science and Arts of Physical Education, Faculty of Physical Education, University of Assiut, pt. (3), N0. (44), (pp.) 290-317. 